ISSN 2587-8123 (Print) ISSN 2658-5995 (Online)

МИНИСТЕРСТВО НАУКИ И ВЫСШЕГО ОБРАЗОВАНИЯ РОССИЙСКОЙ ФЕДЕРАЦИИ ВОЛГОГРАДСКИЙ ГОСУДАРСТВЕННЫЙ УНИВЕРСИТЕТ

НИЖНЕВОЛЖСКИЙ АРХЕОЛОГИЧЕСКИЙ ВЕСТНИК 2021 Tом 20. № 2

MINISTRY OF SCIENCE AND HIGHER EDUCATION OF THE RUSSIAN FEDERATION VOLGOGRAD STATE UNIVERSITY

THE LOWER VOLGA ARCHAEOLOGICAL BULLETIN 2021 Volume 20. No. 2

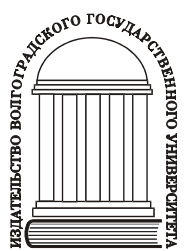




\section{СОДЕРЖАНИЕ}

Конец прекрасной эпохи (Редакциионная коллегия) .... 5

\section{СТАТЬИ}

Файзуллин И.А., Купцова Л.В., Мухаметдинов В.И. Гончарное производство срубной культуры Предуралья по материалам курганного могильника I у села Твердилово

Балабанова М.А., Клепиков В.М., Перерва Е.В. Погребальный обряд и морфология погребенного из кургана могильника Тау (Западный Казахстан) .... 24

Монахов С.Ю. Типология и хронология аканфских амфор [На англ. яз.] 43

Абрамова А.Н. Население Прикубанья раннего железного века по данным краниофенетики (предварительные данные) .66

Малашев В.Ю., Маслов В.Е. Курганы-кладбища центральных и восточных районов Северного Кавказа III в. до н.э. - начала (первой половины) II в. н.э. (памятники типа Чегем-Манаскент)

Ковалева К.С. Производственные

бронзолитейные комплексы

городов Золотой Орды: поиск аналогий

Дрёмов И.И., Круглов Е.В. Железные конусы в погребениях Улуса Джучи:

аспекты этнокультурной принадлежности 149

Гаглойты Р.Х., Кочкаров У.Ю., Мамаев Р.Х., Нарожный В.Е., Нарожный Е.И. Наконечники копий келийского каменноящечного могильника (Горная Ингушетия)

\section{ПУБЛИКАЦИИ}

Кривочеев М.В., Моисеев В.И.

Погребения раннесарматского времени

с территории Чеченской Республики

Иванов С.С. Редкая поясная бляха

в зооморфном стиле с Внутреннего Тянь-Шаня..... 196

Николаев С.Ю. Три сарматских кинжала

с подножия горы Торатау 204

\section{НАУЧНАЯ ЖИЗНЬ}

Итоги VI Нижневолжской Международной археологической научной конференции «Волго-Уральский регион от древности до Средневековья» (Оргкомитет конферениии) 214

\section{CONTENTS}

The End of a Great Era (Editorial Staff) 5

\section{ARTICLES}

Fayzullin I.A., Kuptsova L.V., Mukhametdinov V.I. The Ceramics Production of the Cis-Ural Srubnaya Culture: A Case Study of the Kurgan Cemetery I Near Tverdilovo Village ..... 8

Balabanova M.A., Klepikov V.M., Pererva E.V. Funeral Rite and Morphology of a Buried Man from Kurgan of Tau Cemetery (Western Kazakhstan) .... 24 Monakhov S.Yu. Typology and Chronology of Akanthian Amphorae

Abramova A.N. Craniophenetic Features

of Cis-Kuban Population of the Early Iron Age (Preliminary Data)

Malashev V.Yu., Maslov V.E. Kurgan-Cemeteries of Central and Eastern Regions of North Caucasus $3^{\text {rd }}$ Century BC - Early $2^{\text {nd }}$ Century AD

(Monuments Chegem-Manaskent Type)

Kovaleva K.S. Manufacturing Complexes for the Non-Ferrous Metals Processing of the Golden Horde Cities: Search for Analogies

Dremov I.I., Kruglov E.V. Iron Cones

in the Burials of Ulus Jochi:

Aspects of Ethnocultural Identification

Gagloiti R.H., Kochkarov U.U., Mamaev R.Kh., Narozhnyi V.E., Narozhnyi E.I. Spearheads of the Keliysky Stone Box Burial Ground (Ingushetia Highlands)

\section{PUBLICATIONS}

Krivosheev M.V., Moiseev V.I.

Early Sarmatian Burials

from the Chechen Republic Territory

Ivanov S.S. A Rare Belt Plaque in Zoomorphic Style from the Inner Tien Shan.... 196

Nikolaev S.Yu. Three Sarmatian Daggers

from the Foot of Toratau Mount

\section{SCIENTIFIC LIFE}

Proceedings of the $6^{\text {th }}$ Lower Volga International Scientific Conference on Archaeology

"The Volga-Ural Region -

from Antiquity to the Middle Ages"

(Organizing Committee of the Conference) 214 
www.volsu.ru

DOI: https://doi.org/10.15688/nav.jvolsu.2021.2.2

UDC 930.26(574):393

Submitted: 26.08 .2021

LBC 63.48(5Ка3)-7

Accepted: 30.10 .2021

\title{
FUNERAL RITE AND MORPHOLOGY OF A BURIED MAN FROM KURGAN OF TAU CEMETERY (WESTERN KAZAKHSTAN) ${ }^{1}$
}

\author{
Mariya A. Balabanova \\ Volgograd State University, Volgograd, Russian Federation \\ Valeriy M. Klepikov \\ Volgograd State University, Volgograd, Russian Federation \\ Evgeniy V. Pererva \\ Volgograd State University, Volgograd, Russian Federation
}

\begin{abstract}
Introduction. The paper presents results of the funeral rite and material culture study of the Sauromat time Tau cemetery located on the territory of Western Kazakhstan, and also provides anthropological analysis of the skull discovered there. Methods and materials. An interdisciplinary approach was applied in the course of the study with inclusion of typological, analog and cross-dating methods regarding the funeral rite and material culture examination, methods for studying craniometrical and cranioscopic signs, as well as methods of skull pathology evaluation. The source of the study material as well as the male skull discovery site is burial 1 of kurgan 1 of Tau cemetery. Discussion and results. The funeral rite and clothing inventory data confirms that the burial belongs to Sauromat archaeological culture and, within the chronological framework, could be dated back late $6^{\text {th }}-$ early $5^{\text {th }}$ centuries BC. Furthermore, the funeral rite and weaponry features, including a quiver set with a short sword, attribute this burial to this epoch. Historical and archaeological source analysis suggests that there must have been a cult of the Hand in the Sauromat-Sarmatian society; consequently, the separate interment of the right hand in the examined burial reveals its military trophy origin. The male skull possesses Caucasian features with a weakened horizontal facial profile. The morphological features of the skull from the Tau cemetery have analogies in the synchronous population of Western Kazakhstan, Southern Urals and Lower Volga regions. The skull pathology analysis showed the presence of periodontitis, intravital trauma to the frontal bone, as well as some acute sinusitis signs.
\end{abstract}

Key words: Sauromat culture, gender, age, funeral rite, craniology, pathology, hand symbolism, grave goods.

Citation. Balabanova M.A., Klepikov V.M., Pererva E.V., 2021. Pogrebal'nyy obryad i morfologiya pogrebennogo iz kurgana mogil'nika Tau (Zapadnyy Kazahstan) [Funeral Rite and Morphology of a Buried Man $\overrightarrow{\widetilde{\Upsilon}}$ from Kurgan of Tau Cemetery (Western Kazakhstan)]. Nizhnevolzhskiy Arkheologicheskiy Vestnik [The Lower Volga Archaeological Bulletin], vol. 20, no. 2, pp. 24-42. DOI: https://doi.org/10.15688/nav.jvolsu.2021.2.2

\section{ПОГРЕБАЛЬНЫЙ ОБРЯД И МОРФОЛОГИЯ ПОГРЕБЕННОГО} ИЗ КУРГАНА МОГИЛЬНИКА ТАУ (ЗАПАДНЫЙ КАЗАХСТАН) ${ }^{1}$

\author{
Мария Афанасьевна Балабанова \\ Волгоградский государственный университет, г. Волгоград, Российская Федерация \\ Валерий Михайлович Клепиков \\ Волгоградский государственный университет, г. Волгоград, Российская Федерация \\ Евгений Владимирович Перерва \\ Волгоградский государственный университет, г. Волгоград, Российская Федерация
}


Аннотация. Введение. В статье приводятся результаты исследования погребального обряда и материальной культуры погребения савроматского времени из могильника Тау с территории Западного Казахстана, а также дается антропологическая характеристика происходящего оттуда черепа. Методы и материальы. В статье используется междисциплинарный подход с включением типологического метода, метода аналогий и перекрестного датирования для изучения погребального обряда и материальной культуры, методов исследования краниометрических и краниоскопических признаков, а также методов анализа патологического состояния черепа. Источником исследования является погребение 1 кургана 1 могильника Тау и мужской череп. Обсуждение и результаты. По данным погребального обряда и вещевому инвентарю погребение относится к савроматской археологической культуре и может быть датировано в рамках второй половины VI первой половины $\mathrm{V}$ в. до н.э. Этим временем данное погребение можно датировать, прежде всего, по особенностям погребального обряда и предметам вооружения, представленным колчанным набором и коротким мечом. Анализ исторических и археологических источников позволяет предположить, что в савроматско-сарматском обществе, видимо, присутствовал культ руки, а отдельное захоронение правой руки в исследуемом погребении, очевидно, является воинским трофеем. Череп мужчины характеризуется европеоидными чертами с ослабленной горизонтальной профилировкой лица. Морфологические особенности черепа из могильника Тау имеют аналогии у синхронного населения Западного Казахстана, Южного Приуралья и Нижнего Поволжья. Анализ патологического состояния черепа показал наличие у мужчины пародонтита, прижизненной травмы на лобной кости, а также признаков острого синусита.

Ключевые слова: савроматская культура, пол, возраст, погребальный обряд, краниология, патология, символика руки, вещевой комплекс.

Цитирование. Балабанова М. А., Клепиков В. М., Перерва Е. В., 2021. Погребальный обряд и морфология погребенного из кургана могильника Тау (Западный Казахстан) // Нижневолжский археологический вестник. Т. 20, № 2. C. 24-42. DOI: https://doi.org/10.15688/nav.jvolsu.2021.2.2

\section{Введение}

Погребальный обряд является основным источником реконструкции быта, духовной и материальной культуры, социального устройства и идеологических представлений кочевников, поселенческие памятники которых нам недоступны. При исторической реконструкции по данным археологии обычно пытаются выделять элементы, которые несут определенную символику. Их многообразие отражает сложный характер традиционного миропонимания исследуемого общества. Чтобы понять семантику погребальной обрядности, и прежде всего ее мировоззренческую основу, обращаются к этнографии. Как показывают исследования, в каждой культуре вырисовывается множество процессуальных и предметных групп-символов. Через символ открывается тот или иной смысл предмета или действия. Действия-символы, или процессуальные символы, выражают определенные ценности и идеи при помощи конкретных действий. В контексте темы данной статьи нас в первую очередь интересуют ритуалы, церемонии и обряды, которые реконструируются по археологическим данным.

Целью данного исследования является реконструкция погребального обряда и мате- риальной культуры по материалам савроматского погребения 1 кургана 1 могильника Тау Жанибекского района Западно-Казахстанской области Казахстана; выявление символики отдельных элементов обряда и антропологическая характеристика.

\section{Методика и материал исследования}

Материалом исследования явилось погребение 1 кургана 1 могильника Тау и мужской череп из данного комплекса. И погребение, и череп изучались по традиционной схеме. Вначале дается описание кургана и погребения, его археологическая атрибутика и предположительная семантика погребального обряда, далее приводится индивидуальная краниологическая характеристика измерительных и описательных признаков, а затем - описание его патологического состояния [Алексеев, Дебец, 1964; Рогинский, Левин, 1978; Бужилова, 1995; 1998; Козинцев, 1988; Мовсесян, 2005]. Индивидуальные значения краниометрических признаков, а также признаки, характеризующие патологическое состояние черепа, впервые вводятся в научный оборот и представлены в таблице 1 и на рисунках $3,4$.

В процессе работы с черепом применялась стандартная программа оценки встреча- 
емости на нем патологических состояний, разработанная А.П. Бужиловой [1995; 1998].

Краткая публикация этого комплеса приведена в монографии Б.Ф. Железчикова [1998, с. 40 , рис. $24-25]$

Описание кургана и погребения. Курганный могильник расположен в 5 км к С3 от пос. Тау и представляет собой цепочку курганов из 14 насыпей, вытянутых по гребню естественной возвышенности на целинном поле. Насыпи курганов имеют четко выраженную форму, у многих хорошо заметны ровики. Размеры курганов: высота от 0,2 до 0,45 м, диаметр от 4 до 30 м (рис. 1,1). Некоторые курганы имеют следы ограбления в виде круглых оплывших воронок по центру кургана.

В 1980 г. был раскопан курган № 1, самый крайний в северо-западной части могильника. Его высота на момент исследования составляла 0,31 м, диаметр - 12 м. Вокруг кургана прослеживался ровик глубиной $8 \mathrm{~cm}$, прерывавшийся с ЮВ стороны (рис. 1,2). По всей площади кургана в насыпи на различной глубине были встречены кости овцы и птицы. В центре располагалось погребение 1 . Могильная яма прямоугольной формы была ориентирована длинной осью по линии ЗСЗ - ВЮВ. Длина могильной ямы $-2,5$ м, ширина $-1,7$ м, глубина $-1,4$ м. На дне могильной ямы лежал скелет мужчины на спине вытянуто, головой на 3С3. Правая рука слегка согнута в локте, левая вытянута вдоль туловища. Под костяком зафиксирована меловая посыпка. Справа от костяка лежали кости двух тушек овцы в анатомическом порядке без черепов, рядом с правым плечом обнаружен альчик овцы (рис. 2,1).

Инвентарь погребения 1:

1. Слева от погребенного, рядом с плечевой костью, обнаружены обломки железного предмета, вероятно - колчанного крючка, диаметр прута в сечении - 1,3 см (рис. 2,4).

2. Рядом с костями предплечья были положены, вероятно пучком, бронзовые трехлопастные и трехгранно-трехлопастные втульчатые наконечники стрел в количестве 41 шт. Из них: 15 трехгранно-трехлопастных с короткой выступающей втулкой, длиной от 2,4 до 3,5 см; 7 трехгранно-трехлопастных с глубокими ложками и короткой втулкой, длиной от 2,4 до 3,1 см; 3 трехгранно-трехлопастных с внутренней втулкой, длиной 2,9 см; 13 трехло- пастных с небольшой массивной головкой, короткой выступающей втулкой и опущенным книзу шипом, длиной 2,9-3,2 cм. Во втулках сохранились остатки древков (рис. 2,3).

3. На тазовых костях лежал короткий железный меч с сильно коррозированным бабочковидным (или почковидным) перекрестием и волютообразным навершием. Лезвие в сечении линзовидное. Общая длина меча 43 см, длина клинка - 27 см (рис. 2,2).

4. В ногах погребенного, в юго-западном углу ямы, стоял глиняный лепной горшок с плоским дном, выпуклыми боками, невысокой шейкой и небольшим, слегка отогнутым наружу венчиком. Поверхность светло-коричневого цвета с темными пятнами. Тесто в изломе темное, с примесью извести. Высота сосуда $-20,5$ см, диаметр венчика - 13 см, шейки - 12,2 см, тулова $-17,5$ см, дна -9 см (рис. 2,5).

После снятия костяка и инвентаря, ниже на 10 см, в границах могильной ямы, было прослежено углубление квадратной формы с закругленными углами, со стороной квадрата 1,75 м, где под костями овцы в анатомическом порядке лежали вытянуто кости правой руки человека кистью к ВЮВ. Раскопщиками эта ситуация была определена как наличие второго погребения, однако контекст погребения со всей очевидностью подразумевает ритуальное положение руки в сопутствующий набор погребения № 1.

\section{Анализ}

Индивидуальное захоронение под небольшой насыпью в прямоугольной яме с ориентировкой погребенного головой в западный сектор, в сопровождении напутственной пищи в виде обезглавленных тушек овец, с мечом на поясе и пучком стрел представляет собой классическую погребальную традицию савроматского времени как в Нижнем Поволжье, так и в Волго-Уральском междуречье [Смирнов, 1964, с. 75-100; Очир-Горяева, 1987].

Датировать это погребение позволяют, прежде всего, предметы вооружения, представленные колчанным набором и коротким мечом. Особенностью набора бронзовых наконечников стрел можно назвать наличие в комплекте лавролистных трехлопастных, комбинированных (трехгранно-трехлопастных), 
массивных вариантов и присутствие шипов на втулках, что характерно для первой, ранней группы наборов классического скифского времени, относимого М.А. Очир-Горяевой ко второй половине VI - первой половине V в. до н.э. [Очир-Горяева, 1996, с. 52-54].

Клинковое оружие было атрибутировано Б.Ф. Железчиковым как короткий железный меч с бабочковидным перекрестием и волютообразным навершием [Железчиков, 1998, c. 40 , рис. 25,3$]$. Однако сильно коррозированное перекрестие, представленное в отчете как на рисунке, так и на фото, правильнее было бы определить как почковидное либо как массивное бабочковидное [Мошкова и др., 1980, рис. $285,289,290]$. Такие мечи хорошо представлены в памятниках Нижнего Поволжья, и прежде всего в заволжских степях, к которым можно отнести и территорию, на которой зафиксирован могильник Тау. А.С. Скрипкин выделяет их в группу, датирующуюся второй половиной VI-первой половиной V до н.э. [Скрипкин, 2007, с. 45-47, 50, рис. 2]. Заметим, что комплект оружия по основным характеристикам совпадает с набором вооружения из блюменфельского кургана А12, датированного К.Ф. Смирновым концом VI - началом V в. до н.э. [Смирнов, 1961, рис. $2,1-6, A, 5 ; 1964$, с. 41].

Керамика, представленная лепным горшком с прямым горлом, округлым туловом с наибольшим диаметром в средней части и плоским выделенным дном, была распространена на всем протяжении савроматской культуры, но особенно в VI-V вв. до н.э. [Смирнов, 1964, c. 112].

Особенности погребального обряда. Более подробно остановимся на таком аспекте погребального обряда, как отдельное захоронение костей правой руки, которые в анатомическом порядке располагались под костями обезглавленных туш двух баранов. И обезглавленные туши баранов, и отдельное захоронение руки, видимо, имеют отношение к мировоззрению и мифологической картине мира и выполняют функцию «знаковой системы», отражающейся в обряде посредством действий, предметов и отношений между ними. Анализируя это погребение с точки зрения обрядовых норм и практик, следует остановиться на символике руки как «говорящего» органа человеческого тела.
В научной литературе дается довольно разнообразная тематика, посвященная символике руки, большая часть которой была освещена в работе известного этнолога М.Ф. Альбедиль [2013]. Прежде всего, она дает историю семантического поля руки с разнообразными значениями, начало которого восходит к эпохе верхнего палеолита и соотносится с изображением в пещерной живописи руки. Как пишет этот автор, «тема руки... прошла через всю первобытность и сохранилась в последующие исторические периоды». Исторический анализ показывает, что статус руки в общечеловеческой культуре был высок во все времена и мог быть залогом возвращения к жизни умершего человека [Иванов, 1972, c. 111-113; Толстой, Толстая, 1974; Пропп, 1986, с. 90-92; Байбурин, Топорков, 1990, с. 2348; Маковский, 1996, с. 280, 281; Дэвлет, Дэвлет, 2000, с. 67; Альбедиль, 2013].

Особое место в культуре различных народов занимает тема отрубленной руки и пальцев. Рассмотрим информацию об обряде отсечения руки, который содержится в античных письменных источниках и в фольклоре и имеет косвенное отношение к нашему материалу. Прежде всего следует обратиться к информации, приведенной в «Истории» Геродота (IV. 62), который, описывая воинские обряды скифов в эпизоде жертвоприношения скифскому богу войны Аресу, пишет, что «у заколотых жертв отрубают правые плечи с руками и бросают их в воздух». Кроме этого сюжета Геродот (IV.64) приводит аналогичные обычаи соседних со скифами народов (не уточняя каких). Они, в свою очередь, тоже лишали врага правой руки, но из содранной вместе с ногтями кожи изготавливали чехлы для своих колчанов.

В другом античном источнике есть информация о том, что в битве за престол Артаксеркс отчленил голову и правую руку у трупа своего поверженного брата Кира. Плутарх (Артаксеркс, 13), описавший этот эпизод, говорит, что обряд Артаксеркс совершил по какому-то персидскому обычаю. Видимо, и отсеченная голова, и правая рука тоже символизировали победу над братом.

Ф.М. Таказов [2015, с. 144] обычай отсечения руки у нартов возводит к скифским параллелям и отмечает, что обряд имел широкое распространение на Кавказе вплоть до на- 
чала XX столетия. Видимо, и мотивация, и семантика отсечения руки на Кавказе со временем менялись, тем не менее связь с воинскими традициями прослеживается повсеместно.

Отдельно тема воинских обычаев и обрядов в осетинском нартовском эпосе рассматривается в недавно опубликованной работе Л.А. Чибирова и Г.Н. Вольной (Керцевой) [2020]. В ней наряду с другими обрядами дается атрибутика обряда отсечения руки [Чибиров, Вольная (Керцева), 2020, с. 11, 12].

В этнографии осетин В.А. Цагараев [2000, c. 242] описывает обычай расправы с кровником - отрубание правой руки или кисти.

Кроме письменных источников обряд отсечения руки или различные манипуляции с рукой и пальцами были зафиксированы в скифо-савромато-сарматских погребальных комплексах. Можно выделить три группы публикаций: в одной рассматриваются особенности погребального обряда, связанные с положением или отсутствием руки, в другой дается семантика культа руки, а в третьей - приводятся скифо-сарматские параллели.

Чаще всего нестандартное положение руки или ее отсутствие отмечают при раскопках элитных комплексов и не только [Ковпаненко, 1986; Прохорова, Гугуев, 1992; Батиева, Прохорова, 1998; Зайцев, Мордвинцева, 2004; Десятерик, 2019; и др.].

В результате этих исследований была выделена «женская» черта сарматской погребальной практики - положение рук на тазе [Симоненко, 1993; Максименко, 1998; Дзиговский, Островерхов, 2008; и др.]. А.В. Симоненко наличие этого обряда связывает с бинарными оппозициями типа «невеста - жена», «девушка - женщина» и т. п. [1993, с. 79]. Аналогичные обычаи были отмечены В.С. Ольховским и в скифской погребальной практике [1991, с. 158]. Встречаются они и в древнегреческих погребальных обрядах. При этом положение обеих рук или же только левой руки на тазе отмечено в женских погребениях, а правой - в мужских [Масленников, 1985, с. 67, 68].

В связи с тем что в исследуемом погребении присутствует отдельное захоронение костей правой руки, следует более подробно остановиться и на этом аспекте обряда. В вышеприведенной обрядовой практике скифов у Геродота фигурирует правая рука. Семанти- ка правой / левой руки, которую дают исследователи Н.И. Толстой и С.М. Толстая [1974, с. 49], носила значение знаков-антагонистов: правая рука выполняла положительную функцию и имела связь с удачей, благополучием, безопасностью, а левая - отрицательную и ассоциировалась с несчастьем и неблагополучием.

В первой главе монографии А.К. Байбурина и А.Л. Топоркова «У истоков этикета» [1990, с. 23-48] отмечается: «Для некоторых поздних форм этикета, видимо, важнее оказалось то обстоятельство, что правая (мужская) сторона оценивалась как более почетная, нежели левая (женская)».

Тема мужское / женское и правое / левое в сарматской погребальной практике рассматривается в статье Д.В. Пикалова [2014, c. 151-153]. В ней он дает интерпретацию обряда сарматского парного погребения 7 кургана 7 у с. Китаевка Ставропольского края. В этой могиле у мужского костяка отсутствовала правая рука, у женского - левая. Это противопоставление «левый - правый», по мнению автора, связано с близнечными мифами, и на этой основе он предполагает захоронение близнецов. Не исключает автор и ситуации, когда обряд отсечения рук у близнецов с посмертными манипуляциями носил магический характер.

Вышеприведенная семантика правое / левое и мужское / женское, видимо, была присуща многим народам древности и современности и зафиксирована в культуре традиционного жилища: левая - женская сторона, а правая - мужская.

Вернемся к интерпретации отсечения руки, которую дают исследователи на основе текстов осетинского нартовского эпоса, когда врагу отрубали правую руку, чтобы лишить его полноценных похорон. Л.А. Чибиров солидарен с В.А. Цагараевым [2000] по поводу того, что наряду с головой у пленного отрубали правую руку, так как она была способна «передать на благо обществу сокрытую в своей сакральной зоне большую силу» [Чибиров, 2017, с. 26].

Видимо, культ руки присутствовал у сарматов. Этой теме посвящено исследование А.Н. Дзиговского и А.С. Островерхова [2008], которое построено на анализе амулетов в виде руки, обнаруженных в сарматских погребениях. Кроме того, статья содержит свод археоло- 
гических сарматских источников, в которых был зафиксирован обряд отсечения руки.

Воинскую атрибутику представляют собой обряды, отраженные в осетинском нартовском эпосе. Тематика отсечения руки засвидетельствована в сказаниях, например в таких: «Как Батрадз отомстил за смерть отца», «Как нарт Батрадз нашел Бурадзага», «Яблоко нартов», «Сослан и Тотрадз», «Сослан и безвестный сын Уархага» и др. [Нарты, 1989; Чибиров, Вольная (Керцева), 2020]. Во всех текстах обращается внимание на то, что повреждение руки или рук врага-противника воспринимается как победа над ним. В этом случае отсеченная рука является доказательством убийства врага и трофеем победителя. Обратная ситуация связана с тем, что быть похороненным без головы или руки считалось позором для нартовского героя.

Таким образом, анализ имеющейся литературы позволяет говорить, что обряд отсечения правой руки является мужским признаком, а также признаком позорной смерти, и связан он был с воинскими обрядами. В связи с атрибутикой исследуемого погребения как воинского можно предположить, что захоронение в нем руки может являться военным трофеем. Археолого-этнологический анализ может быть дополнен анализом антропологическим.

Индивидуальная характеристика чере$n a$. Для определения пола на черепе рассматривался комплекс признаков полового диморфизма, который позволил определить его как мужской. Об этом свидетельствует как относительно общая его массивность, так и отдельно взятые признаки, сформированные по мужскому типу [Алексеев, Дебец, 1964; Рогинский, Левин, 1978]. К ним, прежде всего, следует отнести сильно наклонный лоб; хорошо развитый лобный рельеф с крупными надбровными дугами и сосцевидными отростками; мощный наружный затылочный бугор; массивную нижнюю челюсть с развернутыми углами и почти прямым углом ветвей и др.

Для определения возраста рассматривалось общее физическое состояние черепа на момент смерти. Сочетание степени стертости зубов и облитерации черепных швов позволяет определить возраст мужчины в пределах 40-50 лет. Следует отметить, что, хотя и наблюдается полная облитерация черепных швов как со стороны эндокрана, так и снаружи, степень стертости зубов, особенно на нижней челюсти, не позволяет определить возраст мужчины старше 40-50 лет. К тому же на черепе наблюдается большое несоответствие стертости зубов на нижней и верхней челюстях. На нижней челюсти стертость значительно меньше, чем на верхней. На черепе была отмечена посмертная правосторонняя деформация, поэтому часть краниологических признаков не удалось измерить, другая часть в таблице 1 дается под вопросом.

Краниометрическая программа включала около 90 признаков и указателей, а краниоскопическая программа - более 20 признаков [Алексеев, Дебец, 1964]. При фиксации дискретно-варьирующих признаков использовались программы исследования, разработанные отечественными и зарубежными учеными [Козинцев, 1988; Мовсесян, 2005; и др.].

Череп крупный, длинный, широкий, по указателю долихокранный (табл. 1, рис. 3) [Алексеев, Дебец, 1964, с. 114-117]. Вертикальная норма черепа ближе к эллипсоидной. Рельеф на черепе развит выше среднего. Лобная кость средней ширины, резко профилированная по линии фронто-темпоральных точек и покатая по углу назион-метопион [Рогинский, Левин, 1978, c. 98]. Ее хорда и дуга средней длины. У теменной кости хорда длинная, а дуга средней длины. Затылочная кость очень широкая с короткой хордой и среднедлинной дугой.

Лицевой скелет очень крупный, высокий и широкий со слабой горизонтальной профилировкой на уровне глазниц и умеренной на уровне зигомаксилярных точек. Вертикальный профиль лица с тенденцией к прогнатизму. Альвеолярная дуга средней длины и широкая, а небо узкое. Нос высокий среднеширокий, лепторинный по пропорции, а форма грушевидного отверстия устроена по типу предносовые ямки. Глазница очень широкая и низкая и по абсолютной ширине, и по указателю (хамэконхная). По ширине глазницы наблюдается асимметрия: правая глазница шире, чем левая. Переносье узкое и высокое, а носовые кости узкие и низкие и резко выводят нос к линии профиля. Клыковая ямка мелкая.

Из эпигенетических признаков на черепе следует отметить наличие надглазничного отверстия слева; дополнительного подглазнич- 
ного отверстия тоже слева; теменного отверстия справа; небольших ореховидных вздутий на нижней челюсти; отверстия на скуловых костях и подглазничный узор, сформированный по типу II с обеих сторон [Мовсесян, 2005; Козинцев, 1988].

Нижняя челюсть очень крупных поперечных размеров с хорошим очертанием подбородочной части. Проекционная длина от углов и длина от мыщелков очень большие. Передняя ширина нижней челюсти, высота симфиза, высота ветви и наименьшая ширина ветви также имеют очень большие размеры. Малые значения имеет угловая ширина 93 мм. Угол ветви челюсти очень маленький.

Комплекс признаков на черепе позволяет диагностировать его как европеоидный расовый, несмотря на умеренную горизонтальную профилировку лица. Аналогичный набор признаков встречается как на материалах савроматского времени Нижнего Поволжья, так и Западного Казахстана и Южного Приуралья [Балабанова, 2000, с. 45-49; 2018, с. 42; Китов, Мамедов, 2014, с. 195, 300-303].

Патология. В процессе проведения патологического анализа краниума и нижней челюсти индивида удалось установить следующее. Черепная коробка носит на себе следы посмертной деформации, которая возникла в результате сильного давления земляной массы на мозговую капсулу. В то же время следует указать на то, что кость хорошо сохранилась и надкостница не повреждена. Однако часть основания черепа разрушилась, в связи с чем отсутствуют затылочные мыщелки и мыщелок нижней челюсти с правой стороны.

Обследование черепной капсулы показало наличие на надбровных дугах признаков васкулярной реакции по типу «апельсиновой корки» первого балла по А.П. Бужиловой [1998] (рис. 4,1). Кроме того, чуть выше левого лобного бугра, в 43 мм от венечного шва, в 66 мм от антропологической точки Bregma и в 49 мм от левого надглазничного края, наблюдается продолговатая вмятина в костной пластине. Дефект имеет форму узкого эллипса, длинной осью ориентированного поперек сагиттального шва: размеры повреждения $20 \times 7$ мм, глубина до 1 мм. Края, стенки и дно дефекта ровные, округлые, покрытые новообразованной надкостницей. Следов прободения в по- лость черепа не выявлено. Признаков воспалительного процесса не зафиксировано. Вероятно, данное повреждение было получено задолго до смерти индивида в результате удара предметом, узким в сечении. Удар был нанесен спереди или сбоку. Ранение имеет прижизненный характер и носит на себе следы удачного полного заживления.

Из других особенностей на черепе следует выделить наличие пальцевидных вдавлений на внутренней поверхности костей свода черепа.

При обследовании основания черепа в области нижнечелюстных бугорков были выявлены признаки деформирующего артроза в виде краевых разрастаний и нарушения анатомической целостности суставной поверхности (рис. 4,4).

Изучение состояния зубной системы показало, что третьи моляры на верхней и нижней челюсти не сохранились и были посмертно утрачены. С правой стороны на нижней челюсти были прижизненно утеряны первый и второй резцы, а с правой стороны - клык (рис. 4,3). С левой стороны верхней челюсти также наблюдается облитерация альвеолярного края в процессе прижизненной утраты первого резца. Квадранты резцов верхней челюсти полностью заросли костной массой, а в области клыка на нижней челюсти с правой стороны наблюдается развитие пародонтального (десневого) кармана (рис. 4,5). Большая часть альвеолярной стенки в области корня зуба разрушена воспалительным процессом. На верхней челюсти, вероятно прижизненно, также были утрачены вторые премоляры и первые моляры с обеих сторон. Квадранты и корневые перемычки данных зубов в альвеолярном отростке разрушены и частично заросли. В области первого премоляра с правой стороны на верхней челюсти имеется выход с наружной поверхности. В результате развития воспалительного процесса верхушки корневых каналов квадрантов первых верхних моляров разрушены и имеют выходы в верхнечелюстные пазухи (рис. 4,2), в которых наблюдается образование периостита, что может указывать на развитие гнойного (острого) синусита. Корни зубов на верхней и нижней челюстях сильно оголены более чем на половину, что указывает на развитие пародонтоза. 
На сохранившихся зубах верхней и нижней челюстей наблюдаются отложения зубного камня желтого цвета (степень выраженности - 2 балла).

Кроме того, у исследуемого индивида наблюдается специфическая стертость передних резцов и клыков, которые изношены намного сильнее, чем премоляры и моляры, на клыках наблюдается стертость до пульпы и образование вторичного дентина.

В результате проведенного исследования следует предположить, что индивид из могильника Тау (курган 1, погребение 1) по набору патологических признаков на черепной коробке и в зубной системе является классическим представителем кочевого населения раннего железного века. Отсутствие на зубах кариеса и развитие периодонтита, сильная стертость зубов и наличие зубного камня - все это является наиболее характерными патологиями зубочелюстной системы кочевников VI-IV вв. до н.э. [Перерва, 2020, с. 180-181].

Прижизненная травма черепа и признаки васкуляризации костной ткани указывают на активный образ жизни индивида, а выявленные следы воспалительного процесса в верхнечелюстных пазухах указывают на острый хронический синусит, которым страдал данный индивид на момент смерти.

\section{Результаты и основные выводы}

Исследуемое погребение по обряду и по сопровождаемому инвентарю, включая вооружение, состоящее из короткого меча и колчанного набора бронзовых наконечников стрел, относится к савроматскому времени и датируется второй половиной VI-первой половиной V в. дон.э.

Анализ письменных источников и сказаний осетинского нартовского эпоса, результатов исследований ученых по семантике руки и пальцев, а также по обряду отсечения руки позволяет выделить несколько аспектов:

1. Обряд отсечения руки можно определить как элемент воинского обряда, который был характерен для многих ираноязычных народов древности, в том числе осетин, через которых, вероятно, распространился на другие кавказские народы.

2. Намеренно изуродованных пленных и скифы, и нарты не хоронили в могилах. Отсе- чение правой руки считалось у них признаком позорной смерти и наряду с отрубленной головой служило воинским трофеем, символизируя окончательную победу над противником.

3. Семантика правой руки связана с мужским началом и несет положительную нагрузку.

4. В связи с тем что исследуемое погребение из могильника Тау атрибутируется как воинское, мы можем связать отдельное захоронение руки в погребении воина как знак одержанной победы над врагом.

По комплексу краниологических признаков, измеренных на черепе из могильника Тау, наблюдается определенное сходство с отдельными черепами савроматского времени как из могильников Западного Казахстана, так и с территории Южного Приуралья и Нижнего Поволжья. Несмотря на довольно уплощенную горизонтальную профилировку лицевого скелета, чисто визуально монголоидные черты на черепе не определяются. Очевидно, вышеприведенный набор признаков характеризует индивидуальные особенности мужчины. Вышеописанные морфологические особенности исследуемого черепа встречаются на синхронных материалах из других могильников Западно-Казахстанской области.

Анализ черепной коробки индивида из погребения 1 кургана 1 могильника Тау позволил выявить ряд патологических состояний, таких как следы от воздействия низких температур или ветров, прижизненная травма черепа со следами удачного заживления, острый синусит обеих верхнечелюстных пазух, признаки гипертензионного синдрома, а также периодонтит с минерализованными отложениями на коронках зубов и сильную стертость передних зубов. Патологии, за исключением периостита и признаков воспалительного процесса в гайморовых пазухах, не препятствовали нормальной жизнедеятельности индивида. Зафиксированный острый синусит мог быть одной из причин его смерти.

\section{ПРИМЕЧАНИЕ}

${ }^{1}$ Исследование выполнено при финансовой поддержке РФФИ в рамках научного проекта № 2029-01020.

The reported study was funded by RFBR, project number 20-29-01020. 


\section{ПРИЛОЖЕНИЯ}

Таблииа 1. Размеры и указатели мужского черепа (40-50 лет) савроматской культуры из погребения 1 кургана 1 могильника Тау

Table 1. Sizes and Markers of Male Skull (40-50 y.o.) of the Sauromat culture from burial 1, kurgan 1

\begin{tabular}{|c|c|c|c|c|c|c|}
\hline $\begin{array}{l}\text { № по Мар- } \\
\text { тину и др. }\end{array}$ & Признак & Значение & $\begin{array}{l}\text { № по Мар- } \\
\text { тину и др. }\end{array}$ & \multicolumn{2}{|l|}{ Признак } & Значение \\
\hline 1 & Продольный диаметр & $188(?)$ & 61 & \multicolumn{2}{|l|}{ Ширина альвеолярной дуги } & 66 \\
\hline 8 & Поперечный диаметр & $140(?)$ & $61: 60$ & \multicolumn{2}{|c|}{ Челюстно-альвеолярный индекс } & 122,2 \\
\hline $8: 1$ & Черепной указатель & 74,4 & 62 & \multicolumn{2}{|c|}{ Длина неба } & - \\
\hline 17 & Высотный диаметр базион-брегма & - & 63 & \multicolumn{2}{|l|}{ Ширина неба } & $36(?)$ \\
\hline $17: 1$ & Высотно-продольный индекс & - & $63: 62$ & \multicolumn{2}{|l|}{ Небный индекс } & - \\
\hline $17: 8$ & Высотно-поперечный индекс & - & 54 & \multicolumn{2}{|l|}{ Ширина носа } & 25 \\
\hline OPB & Общеростовая величина & - & 55 & \multicolumn{2}{|l|}{ Высота носа } & 55 \\
\hline M2 & $\begin{array}{l}\text { Условное трансверсальное се- } \\
\text { чение }\end{array}$ & 263,2 & $54: 55$ & \multicolumn{2}{|l|}{ Носовой указатель } & 44,45 \\
\hline M3 & $\begin{array}{l}\text { Условный трансверсальный } \\
\text { объем }\end{array}$ & - & 51 & \multicolumn{2}{|l|}{ Ширина орбиты (левая) } & 45,5 \\
\hline 5 & Длина основания черепа & - & 52 & \multicolumn{2}{|l|}{ Высота орбиты (левая) } & 33 \\
\hline 20 & Ушная высота порион-порион & $112(?)$ & $52: 51$ & \multicolumn{2}{|l|}{ Орбитный указатель (левая) } & 72,5 \\
\hline 9 & Наименьшая ширина лба & 97 & 51 & \multicolumn{2}{|l|}{ Ширина орбиты (правая) } & 47,0 \\
\hline $\mathrm{h} / 9$ & Высота над ft-ft точками & 20,8 & 52 & \multicolumn{2}{|l|}{ Высота орбиты (правая) } & 33 \\
\hline $\mathrm{h} / 9: 9$ & $\begin{array}{l}\text { Указатель профиля лба над ft-ft } \\
\text { точками }\end{array}$ & 21,4 & $52: 51$ & \multicolumn{2}{|c|}{ Орбитный указатель (правая) } & 70,2 \\
\hline УПИЛ & Угол поперечного изгиба лба & 133,7 & $\mathrm{MC}$ & \multicolumn{2}{|c|}{ Максило-фронтальная ширина } & 17,9 \\
\hline $9: 8$ & Лобно-поперечный & 69,3 & MS & \multicolumn{2}{|c|}{ Максило-фронтальная высота } & 6,4 \\
\hline $9: 10$ & Широтный лобный & 93,3 & MS:MC & \multicolumn{2}{|c|}{ Максило-фронтальный указатель } & 35,8 \\
\hline 10 & Наибольшая ширина лба & 104 & DC & \multicolumn{2}{|c|}{ Дакриальная ширина } & 20 \\
\hline 11 & Ширина основания черепа & $135(?)$ & DS & \multicolumn{2}{|l|}{ Дакриальная высота } & 12 \\
\hline 12 & Ширина затылка & $124 ?$ & DS:DC & \multicolumn{2}{|l|}{ Дакриальный указатель } & 60,0 \\
\hline 25 & Сагиттальная дуга & 369 & $\mathrm{SC}$ & \multicolumn{2}{|l|}{ Симотическая ширина } & 5,8 \\
\hline 26 & Лобная дуга & 127 & SS & Симотическая высота & & 2,1 \\
\hline 27 & Теменная дуга & 125 & SS:SC & Симотический указатель & & 36,2 \\
\hline 28 & Затылочная дуга & 117 & $\mathrm{FC}$ & Глубина клыковой ямки & & 3,0 \\
\hline 29 & Лобная хорда & 112 & $44 \mathrm{a}$ & Бимолярная хорда fmo-fm & & 105,7 \\
\hline 30 & Теменная хорда & 120 & & Высота назиона над б/м х & ордой & 16,0 \\
\hline 31 & Затылочная хорда & $92(?)$ & & Назомалярный индекс & & 15,1 \\
\hline $28: 27$ & Затылочно-теменной индекс & 93,6 & 77 & Назомалярный угол & & 146,4 \\
\hline $29: 26$ & Изгиб лба & 88,2 & & $\begin{array}{l}\text { Зигомаксилярная хорда (п } \\
\text { Абиндеру) }\end{array}$ & & 95,5 \\
\hline $30: 27$ & Изгиб темени & 96,0 & & Высота subspinale над 3/м & ордой & 21,5 \\
\hline $31: 28$ & Изгиб затылка & 78,6 & & Зигомаксилярный индекс & & 22,5 \\
\hline Syb.N $\beta$ & Высота изгиба лба & 24,6 & $<\mathrm{zm}$ & Зигомаксилярный угол & & 131,5 \\
\hline Syb.NB.: 29 & Индекс выпуклости лба & 22,0 & 32 & Угол профиля лба от нази & она & 78 \\
\hline УИЛ & Угол изгиба лба & 132,5 & & Угол профиля лба от глаб & еллы & 65 \\
\hline Syb.N $\beta$ & Высота изгиба затылка & - & 72 & Общий лицевой угол & & 80 \\
\hline Syb.N $\beta .: 31$ & Индекс выпуклости затылка & - & 73 & Угол средней части лица & & 84 \\
\hline УИЗ & Угол изгиба затылка & - & 74 & Угол альвеолярной части & лица & 67 \\
\hline 45 & Скуловой диаметр & $140(?)$ & 75 & $\begin{array}{l}\text { Угол носовых костей к го } \\
\text { зонтали }\end{array}$ & & 50 \\
\hline $45: 8$ & $\begin{array}{l}\text { Поперечный фацио-церебраль- } \\
\text { ный указатель }\end{array}$ & $100(?)$ & $75-1$ & $\begin{array}{l}\text { Угол носовых костей к ли } \\
\text { профиля }\end{array}$ & нии & 30 \\
\hline 40. & Ширина основания лица & - & & Форма и рельеф черел & & \\
\hline $40: 5$ & Указатель выступания лица & - & $\begin{array}{l}\text { Вертикальн } \\
\text { verticales) }\end{array}$ & ая норма черепа (Norma & & soides \\
\hline 48 & Верхняя высота лица & $74(?)$ & Надперенос & ье (по Мартину 1-6) & & 3 \\
\hline $48: 17$ & $\begin{array}{l}\text { Вертикальный фацио-цереб- } \\
\text { ральный указатель }\end{array}$ & - & Надбровны & е дуги & & 2 \\
\hline $48: 45$ & Верхний лицевой уазатель & 52,9 & Сосцевиднн & Ій отросток & & 2 \\
\hline 43 & Верхняя ширина лица & 113 & $\begin{array}{l}\text { Нижний кр } \\
\text { стия }\end{array}$ & ай грушевидного отвер- & Fossa 1 & raenasales \\
\hline 46 & Средняя ширина лица & 95 & Передненос & овая ость & & 3 \\
\hline 60 & Длина альвеолярной дуги & 54 & & & & \\
\hline
\end{tabular}


М.А. Балабанова, В.М. Клепиков, Е.В. Перерва. Погребальный обряд и морфология погребенного

Окончание таблиць 1

End of Table 1

\begin{tabular}{|c|c|c|c|c|c|}
\hline \multicolumn{6}{|c|}{ Нижняя челюсть } \\
\hline $\begin{array}{l}\text { № по Мар- } \\
\text { тину и др. }\end{array}$ & Признак & Значение & $\begin{array}{l}\text { № по Мар- } \\
\text { тину и др. }\end{array}$ & Признак & Значение \\
\hline 65 & Мышелковая ширина & - & 69 & Высота симфиза & 39 \\
\hline 66 & Угловая ширина & 93 & 70 & Высота ветви & 64 \\
\hline 67 & Передняя ширина & 50 & $71(1)$ & Ширина вырезки & 53 \\
\hline 68 & Длина от мыщелков & 90 & $79^{\circ}$ & Угол ветви челюсти & 111 \\
\hline $68(1)$ & Проекционная длина от углов & 108 & & & \\
\hline
\end{tabular}


M.A. Balabanova, V.M. Klepikov, E.V. Pererva. Funeral Rite and Morphology of a Buried Man
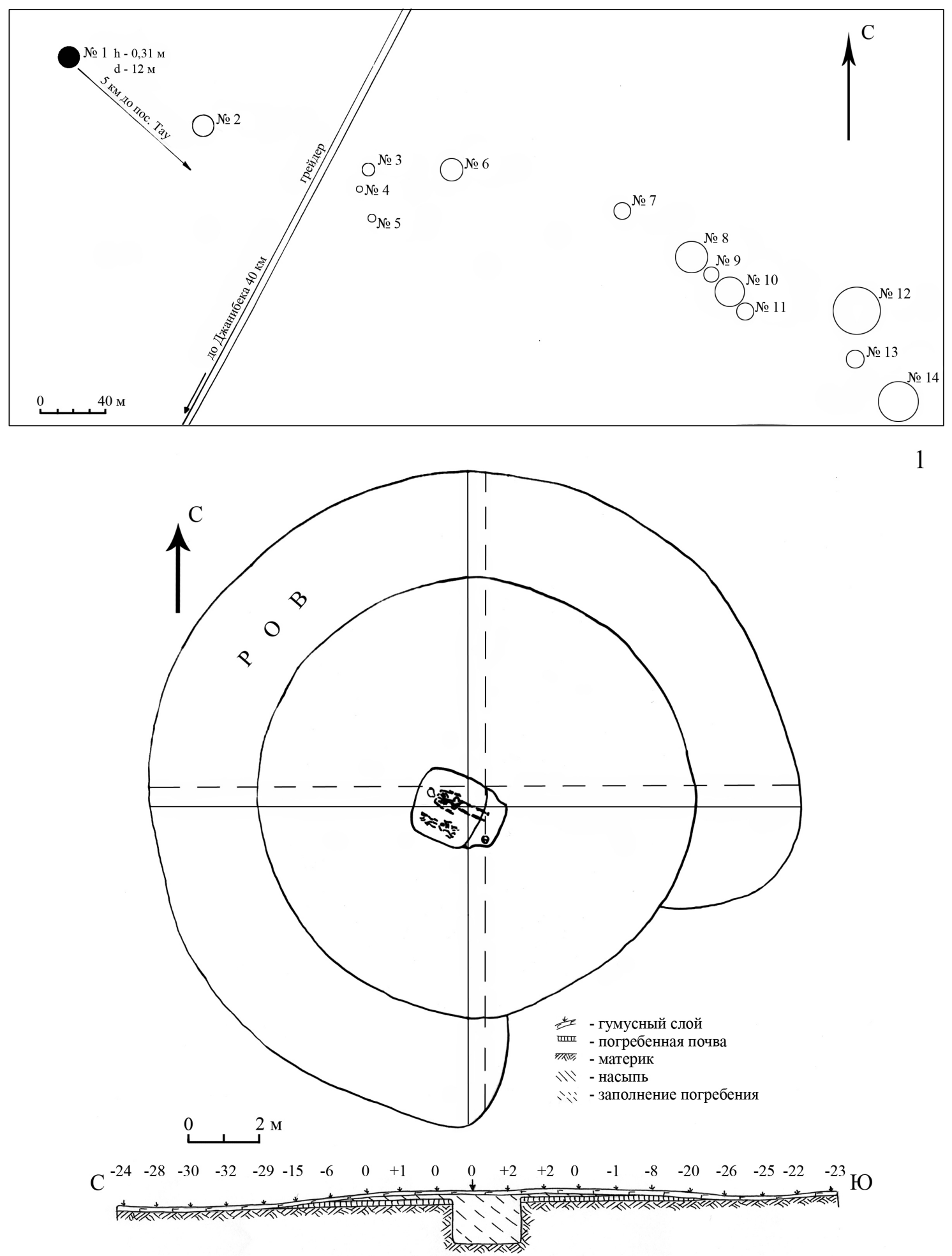

$\begin{array}{lllllllllllllllllllllll}3 & -28 & -28 & -34 & -36 & -28 & -13 & -6 & -2 & -1 & +2 & 0 & +3 & -1 & -1 & -6 & -13 & -25 & -32 & -33 & -25 & -19 & \mathrm{~B}\end{array}$

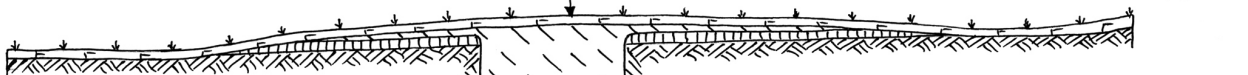

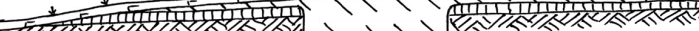

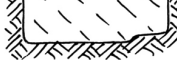

Рис. 1. Курганный могильник Тау:

1 - план курганного могильника Тау; 2 - план и профили бровок кургана 1

Fig. 1. Tau kurgan cemetery:

1 - Tau kurgan cemetery layout ; 2 - layout and profiles of kurgan 1 
М.А. Балабанова, В.М. Клепиков, Е.В. Перерва. Погребальный обряд и морфология погребенного

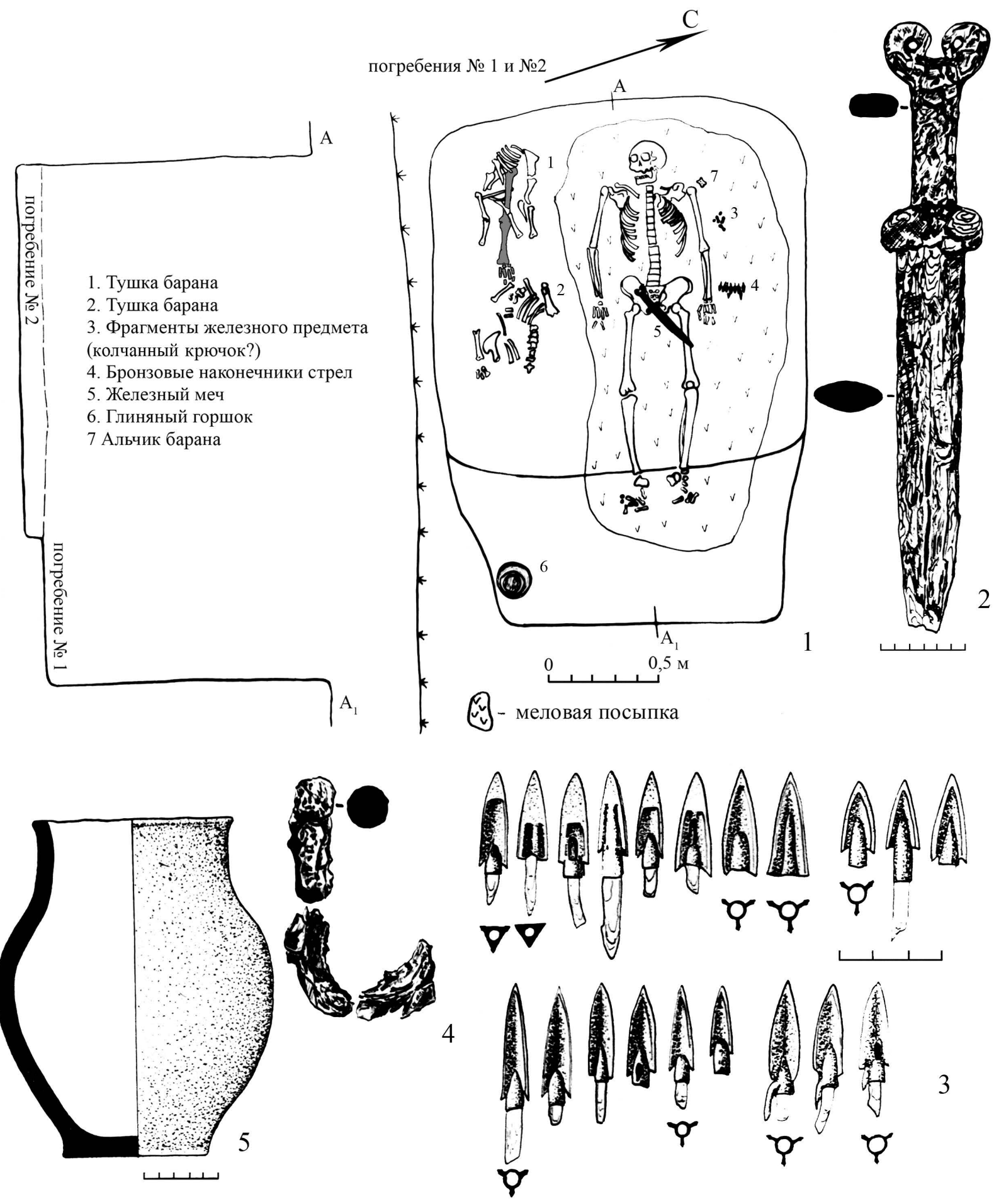

Рис. 2. Курганный могильник Тау. Погребение 1:

1 - план и разрез погребения № 1; инвентарь погребения 1: 2 - железный меч; 3 - бронзовые наконечники стрел; 4 - железный колчанный крючок; 5 - глиняный лепной горшок

Fig. 2. Tau kurgan cemetery. Burial 1:

1 - burial 1 plan and sectional drawing; grave goods of burial 1: 2 - iron sword; 3 - bronze arrowheads;

4 - iron quiver hook; 5 - clay molded pot 

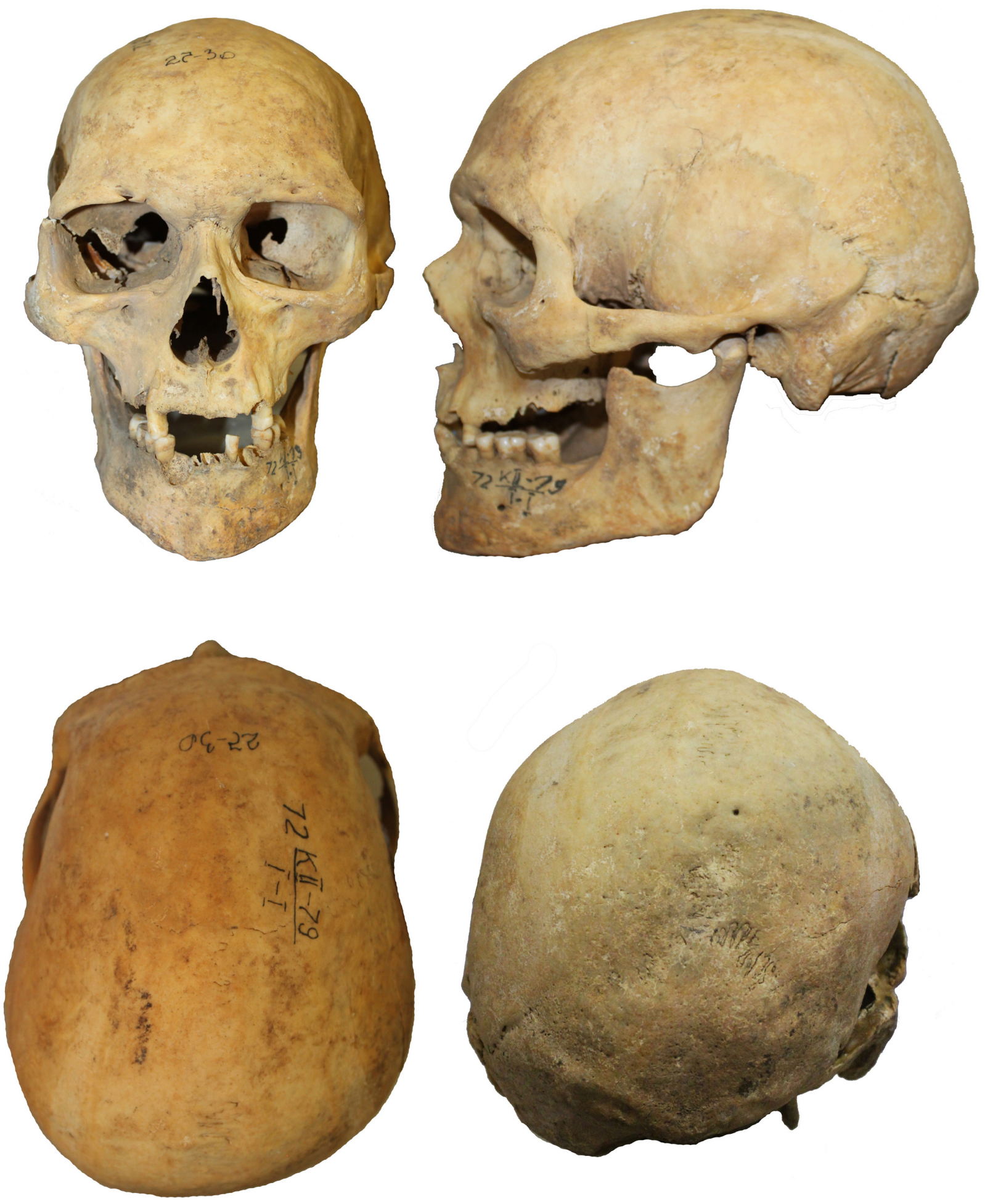

Рис. 3. Череп мужчины (40-50 лет) из погребения 1 кургана 1 могильника Тау

Fig. 3. Male Skull (40-50 y.o.) from burial 1, kurgan 1 of Tau kurgan cemetery 


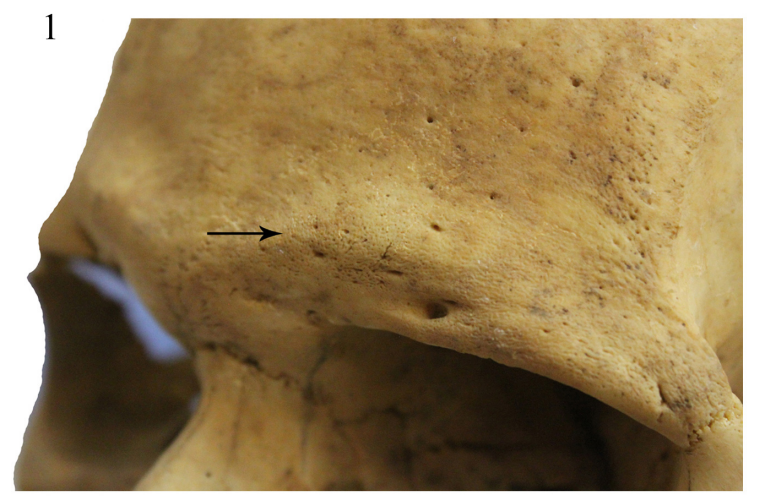

3
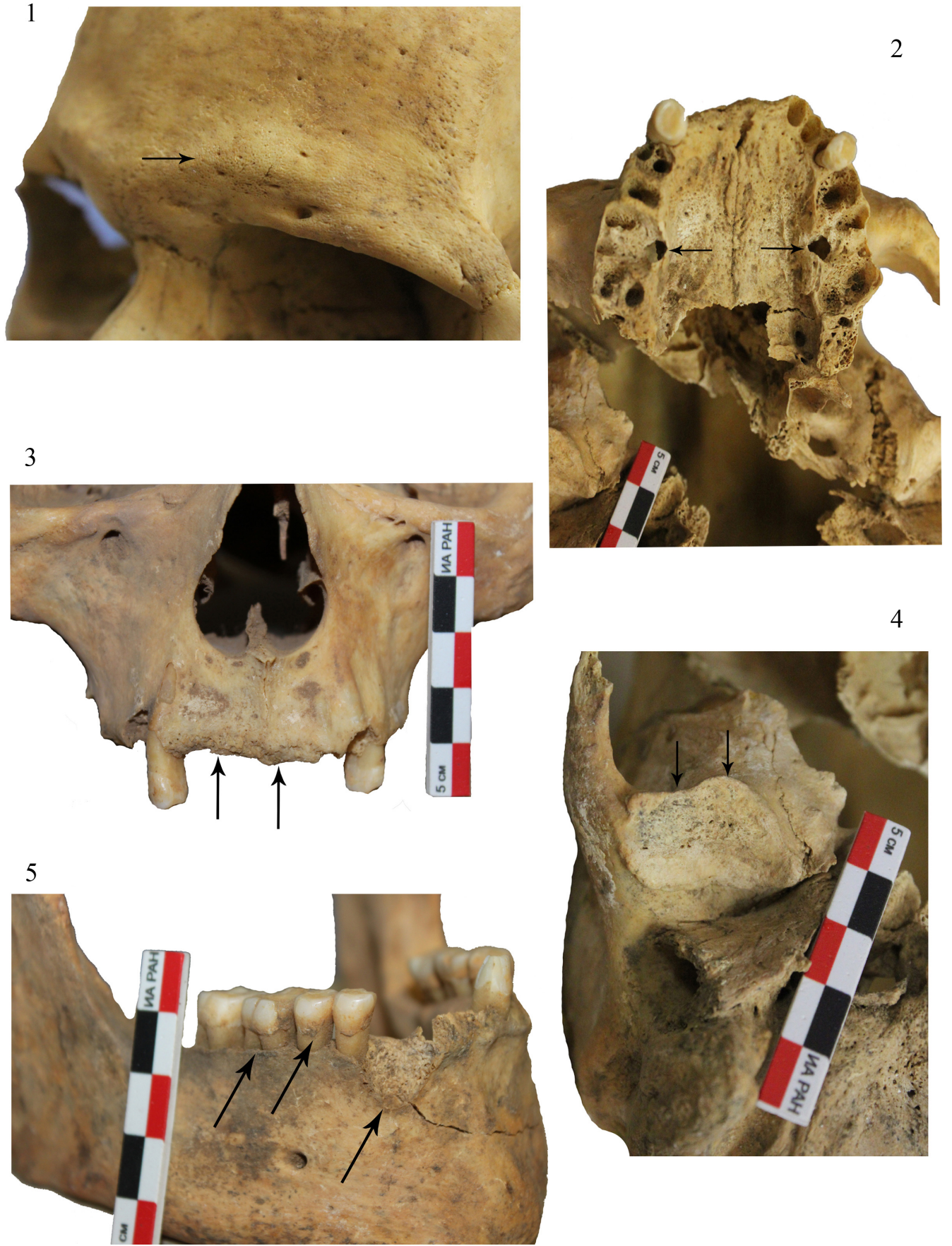

Рис. 4. Патологические отклонения, выявленные на черепной капсуле и нижней челюсти мужчины из погребения 1 кургана 1 могильника Тау:

1 - васкулярная реакция по типу «апельсиновой корки»; 2 - признаки периодонтита и выходы от воспалительного процесса в области корней первых моляров в верхнечелюстные пазухи;

3 - прижизненная утрата передних резцов верхней челюсти; 4 - деформирующий артроз

в области нижнечелюстной ямки и суставного бугорка (правая височная кость); 5 - пародонтальный карман в область альвеолярной стеки правого клыка на нижней челюсти с наружной стороны, зубной камень и следы пародонтоза нижней челюсти

Fig. 4. Pathological abnormalities revealed on the cranial capsule and the lower jaw of a man from burial 1 of kurgan 1 of the Tau cemetery:

1 - Vascular reaction of the "orange peel" type; 2 - Periodontitis signs and the first molars outlets into root area of the maxillary sinuses due to inflammatory process; 3 - Intravital loss of the upper jaw anterior incisors;

4 - Deforming arthrosis in mandibular fossa and articular tubercle area (right temporal bone); 5 - Periodontal pocket of the right canine alveolar stack area on the lower jaw from the outside, tartar and periodontal disease traces of the lower jaw 


\section{СПИСОК ЛИТЕРАТУРЫ}

Алексеев В. П., Дебец Г. Ф., 1964. Краниометрия. Методика антропологических исследований. М. : Наука. $127 \mathrm{c}$.

Альбедиль М. Ф., 2013. Ты держишь мир в простертой длани: символика руки // Теория моды. № 27. С. 156-172.

Байбурин А. К., Топорков А. Л., 1990. У истоков этикета : этнографические очерки. Ленинград : Наука. 165 с.

Балабанова М. А., 2000. Антропология древнего населения Южного Приуралья и Нижнего Поволжья. Ранний железный век. М. : Наука. 133 с.

Балабанова М. А., 2018. Этногенетические связи ранних кочевников VI-I вв. до н. э. (по материалам могильников Западного Казахстана, Южного Приуралья, Нижнего Поволжья и Нижнего Дона) // Вестник Волгоградского государственного университета. Серия 4, История. Регионоведение. Международные отношения. Т. 23, № 3. С. 37-51. DOI : https://doi.org/10.15688/jvolsu4.2018.3.4.

Батиева Е. Ф., Прохорова Т. А., 1998. Антропология погребения из кургана 10 Кобяковского могильника и мифоритуальная роль руки у сарматов // VII Донская археологическая конференция «Проблемы археологии Юго-Восточной Европы» (г. Ростов-на-Дону, 22-26 ноября 1998 г.) : тез. докл. Ростов н/Д : Ин-т «Открытое общество». С. 85-86.

Бужилова А. П., 1995. Древнее население (палеопатологические исследования). М. : ИА РАН. 189 с.

Бужилова А. П., 1998. Палеопатология в биоархеологических реконструкциях // Историческая экология человека. Методика биологических исследований. М. : Старый сад. С. 87-147.

Десятерик Д. И., 2019. Существенная черта погребального ритуала сарматской царицы // Альманах «Начало». № 1. С. 14-20. DOI: https://doi.org/10.5281/zenodo.3674791.

Дзиговский А. Н., Островерхов А. С., 2008. Культ руки у сарматов // Краткие сообщения Одесского археологического общества. Одесса : Печатный дом «Фаворит». С. 167-172.

Дэвлет Е., Дэвлет М., 2000. Духовная культура древних народов Северной и Центральной Азии (мир петроглифов). Т. 7. Сер. Российские исследования по мировой истории и культуре. Нью-Йорк : New Yourk Press. $502 \mathrm{c}$.

Железчиков Б. Ф., 1998. Археологические памятники Уральской области. Волгоград : Изд-во ВолГУ. 136 с.

Зайцев Ю. П., Мордвинцева В. И., 2004. «Царица» из Ногайчинского кургана: возможности исторических реконструкций // Боспорский феномен. Т. 2. СПб. : Гос. Эрмитаж. С. 290-297.

Иванов Вяч. Вс., 1972. Об одном типе архаических знаков искусства и пиктографии // Ранние формы искусства. М. : Искусство. С. 105-141.

Китов Е. П., Мамедов А. М., 2014. Кочевое население Западного Казахстана в раннем железном веке. Астана : Изд. группа ФИА им. А.Х. Маргулана в г. Астана. 352 с.

Ковпаненко Г. Т., 1986. Сарматское погребение I в. н.э. на Южном Буге. Киев : Наукова думка. 149 с.

Козинцев А. Г., 1988. Этническая краниоскопия. Расовая изменчивость швов черепа современного человека. Л. : Наука. 167 c.

Маковский М. М., 1996. Сравнительный словарь мифологической символики в индоевропейских языках : Образ мира и миры образов. М. : Гуманит. изд. центр «ВЛАДОС». 415 с.

Максименко В. Е., 1998. Сарматы на Дону // Донские древности. Вып. 6. Азов : Изд-во Азов. краевед. музея. $304 \mathrm{c}$.

Масленников А. А., 1985. Некрополи городов Азиатского Боспора в первые в. н.э. // Советская археология. № 1. C. 61-74.

Мовсесян А. А., 2005. Фенетический анализ в палеоантропологии. М. : Унив. кн. 272 с.

Мошкова М. Г., Железчиков Б. Ф., Кригер В. А., 1980. Отчет об археологических работах на территории Уральской области в 1980 г. // Архив ИА им. А. Маргулана НАН РК. Оп. 2. Д. 1838.

Нарты, 1989. Осетинский героический эпос. В 3 кн. Кн. 2. М. : Наука. 492 с.

Ольховский В. С., 1991. Погребально-поминальная обрядность населения Степной Скифии (VII-III вв. дон. э.). М. : Наука. 253 с.

Очир-Горяева М. А., 1987. Погребальный обряд населения Нижнего Поволжья и Южного Приуралья VIIV вв. до н.э. // Археологические исследования Калмыкии. Элиста : КНИИ ИФЭ. С. 35-53. 
Очир-Горяева М. А., 1996. Наконечники стрел кочевников Нижнего Поволжья // Российская археология. № 1. C. 41-54.

Перерва Е. В., 2020. Палеопатологические особенности кочевников савроматского времени с территории Нижнего Поволжья // Genesis : исторические исследования. № 12. C. 171-183. DOI: https://doi.org/10.25136/ 2409-868X.2020.12.34412.

Пикалов Д. В., 2014. Близнечный культ и обычай отрубания руки у сармат // Труды IV (XX) Всероссийского археологического съезда в Казани. Т. II. Казань : Отечество. С. 150-153.

Пропп В. Я., 1986. Исторические корни волшебной сказки. Л. : Изд-во ЛГУ. 364 с.

Прохорова Т. А., Гугуев В. К., 1992. Богатое сарматское погребение в кургане 10 Кобяковского могильника // Советская археология. № 1. С. 142-161.

Рогинский Я. Я., Левин М. Г., 1978. Антропология : учеб. для студ. ун-тов. М. : Высш. шк. 528 с.

Симоненко А. В., 1993. Сарматы Таврии. Киев : Наукова думка. 144 с.

Скрипкин А. С., 2007. Клинковое оружие ранних кочевников Нижнего Поволжья VII-IV вв. до н. э. (проблемы хронологии) // Вооружение сарматов: региональная типология и хронология : докл. к VI Междунар. конф. «Проблемы сарматской археологии и истории». Челябинск : Изд. центр ЮУрГУ. С. 38-50.

Смирнов К. Ф., 1961. Вооружение савроматов. МИА. № 104. М. : АН СССР. 101 с.

Смирнов К. Ф., 1964. Савроматы. Ранняя история и культура сарматов. М. : АН СССР. 377 с.

Таказов Ф. М., 2015. Обычай отрубания руки: скифо-нартовские параллели // Нартоведение в XXI веке : Современные парадигмы интерпретации. № 3. С. 142-151.

Толстой Н. И., Толстая С. М., 1974. К семантике правой и левой стороны в связи с другими символическими элементами // Материалы Всесоюзного симпозиума по вторичным моделирующим системам. № 1 (5). Тарту: Тарт. гос. ун-т. С. 42-45.

Цагараев В. А., 2000. Золотая яблоня нартов: история, мифология, искусство, семантика. Владикавказ : Респуб. издат.-полигр. предприятие им. В.А. Гассиева. 299 с.

Чибиров Л. А., 2017. Правая рука - десница: скифо-осетинские параллели // Вестник Владикавказского научного центра. Т. 17, № 2. С. 24-27.

Чибиров Л. А., Вольная (Керцева) Г. Н., 2020. Воинские обычаи и обряды в осетинском нартовском эпосе: истоки и параллели // Известия СОИГСИ. Вып. 37 (76). С. 5-16.

\section{REFERENCES}

Alekseev V.P., Debets G.F., 1964. Kraniometriya. Metodika antropologicheskikh issledovaniy [Craniometry. Technique of Anthropological Research]. Moscow, Nauka Publ. 127 p.

Al'bedil' M.F., 2013. Ty derzhish' mir v prostertoy dlani: simvolika ruki [You Hold the World in Your Outstretched Hand: The Symbolism of the Hand]. Teoriya mody [Fashion Theory], no. 27, pp. 156-172.

Bayburin A.K., Toporkov A.L., 1990. U istokov etiketa: etnograficheskie ocherki [At the Origins of Etiquette: Ethnographic Essays]. Leningrad, Nauka Publ. 165 p.

Balabanova M.A., 2000. Antropologiya drevnego naseleniya Yuzhnogo Priuralya i Nizhnego Povolzhya. Ranniy zheleznyy vek [Anthropology of the Ancient Population of the Southern Urals and the Lower Volga Region. Early Iron Age]. Moscow, Nauka Publ. 133 p.

Balabanova M.A., 2018. Etnogeneticheskie svyazi rannih kochevnikov VI-I vv. do n. e. (po materialam mogil'nikov Zapadnogo Kazahstana, Yuzhnogo Priural'ya, Nizhnego Povolzh'ya i Nizhnego Dona) [Ethnogenetic Connections of Early Nomads in the $6^{\text {th }}-1^{\text {st }}$ CC. BC (Based on the Materials of Burial Mounds of Western Kazakhastan, the Southern Cisurals, the Lower Volga Region and the Lower Don Region)]. Vestnik Volgogradskogo gosudarstvennogo universiteta. Seriya 4. Istoriya. Regionovedenie. Mezhdunarodnye otnosheniya [Science Journal of Volgograd State University. History. Area Studies. International Relations], vol. 23, no. 3, pp. 37-51. DOI: https://doi.org/10.15688/jvolsu4.2018.3.4.

Batieva E.F., Prohorova T.A., 1998. Antropologiya pogrebeniya iz kurgana 10 Kobyakovskogo mogil'nika i miforitual'naya rol' ruki u sarmatov [The Anthropology of Burial from Kurgan 10 of the Kobyakovskiy Cemetery and the Mythological Role of the Hand among the Sarmatians]. VII Donskaya arheologicheskaya konferentsiya «Problemy arheologii Yugo-Vostochnoy Evropy» (Rostov-na-Donu, 22-26 noyabrya 1998 g.): 
tez. dokl. [VII Don Archaeological Conference "Problems of Archeology of South-Eastern Europe" (Rostovon-Don, November 22-26, 1998). Abstracts of reports]. Rostov-on-Don, Institut «Otkrytoe obschestvo» Publ., pp. 85-86.

Buzhilova A.P., 1995. Drevnee naselenie (paleopatologicheskie issledovaniia) [Ancient Population (Paleopathological Research)]. Moscow, IA RAS. 189 p.

Buzhilova A.P., 1998. Paleopatologiia v bioreologicheskikh rekonstruktsiiakh [Paleopathology in Biorheological Reconstructions]. Istoricheskaia ekologiia cheloveka. Metodika biologicheskikh issledovanii [Historical Human Ecology. Biological Research Technique]. Moscow, Staryy Sad Publ., pp. 87-147.

Desyaterik D.I., 2019. Sushchestvennaya cherta pogrebal'nogo rituala sarmatskoj caricy [An Essential Feature of the Funeral Ritual of the Sarmatian Queen]. Al'manah «Nachalo» [Almanac “The Beginning”], no. 1, pp. 14-20. DOI: https://doi.org/10.5281/zenodo.3674791.

Dzigovskiy A.N., Ostroverhov A.S., 2008. Kul't ruki u sarmatov [The Cult of the Hand of the Sarmatians]. Kratkie soobshcheniya Odesskogo arheologicheskogo obshchestva [Brief Reports of the Odessa Archaeological Society]. Odessa, Pechatnyy Dom «Favorit», pp. 167-172.

Devlet E., Devlet M., 2000. Duhovnaya kul'tura drevnih narodov Severnoy i Central'noy Azii (mir petroglifov) [Spiritual Culture of the Ancient Peoples of North and Central Asia (the World of Petroglyphs). Vol. 7. Ser. Russian Studies on World History and Culture]. New York, New York Press. 502 p.

Zhelezchikov B.F., 1998. Arheologicheskie pamyatniki Ural 'skoy oblasti [Archaeological Sites of the Ural Region]. Volgograd, VolSU. $136 \mathrm{p}$.

Zaycev Yu.P., Mordvintseva V.I., 2004. «Tsaritsa» iz Nogaychinskogo kurgana: vozmozhnosti istoricheskih rekonstruktsiy ["The Queen" from the Nogaichinsky Kurgan: The Possibilities of Historical Reconstructions]. Bosporskiy fenomen [Bosporus Phenomenon], vol. 2. St. Petersburg, State Hermitage, pp. 290-297.

Ivanov Vyach. Vs., 1972. Ob odnom tipe arhaicheskih znakov iskusstva i piktografii [About one Type of Archaic Signs of Art and Pictography]. Rannie formy iskusstva [Early Forms of Art]. Moscow, Iskusstvo Publ., pp. 105-141.

Kitov E.P., Mamedov A.M., 2014. Kochevoe naselenie Zapadnogo Kazahstana v rannem zheleznom veke [The Nomadic Population of Western Kazakhstan in the Early Iron Age]. Astana, Publishing group of BIA named after A.H. Margulan in Astana. $352 \mathrm{p}$.

Kovpanenko G.T., 1986. Sarmatskoe pogrebenie Iv. n.e. na Yuzhnom Buge [Sarmatian Burial of the First Century AD on the Southern Bug]. Kiev, Naukova dumka Publ. 149 p.

Kozintsev A.G., 1988. Etnicheskaya kranioskopiya. Rasovaya izmenchivost' shvov cherepa sovremennogo cheloveka [Ethnic Cranioscopy. Racial Variability of the Sutures of the Skull of a Modern Person]. Leningrad, Nauka Publ. $167 \mathrm{p}$.

Makovskiy M.M., 1996. Sravnitel'nyy slovar' mifologicheskoy simvoliki v indoevropeyskih yazykah: Obraz mira i miry obrazov [Comparative Dictionary of Mythological Symbolism in Indo-European Languages: The Image of the World and the Worlds of Images]. Moscow, Gumanitarnyy izdatel'skiy Tsentr VLADOS Publ. $415 \mathrm{p}$.

Maksimenko V.E., 1998. Sarmaty na Donu [Sarmatians on the Don]. Donskie drevnosti, iss. 6. Azov, Azov Museum of Local Lore. 304 p.

Maslennikov A.A., 1985. Nekropoli gorodov Aziatskogo Bospora v pervye v. n.e. [Necropolises of the Asiatic Bosporus in the First Centuries A.D.]. Sovetskaya arheologiya [Soviet Archeology], no. 1, pp. 61-74.

Movsesyan A.A., 2005. Feneticheskiy analiz v paleoantropologii [Phenetic Analysis in Paleoanthropology]. Moscow, Universitetskaya kniga Publ. 272 p.

Moshkova M.G., Zhelezchikov B.F., Kriger V.A., 1980. Otchet ob arheologicheskih rabotah na territorii Ural'skoy oblasti v 1980 g. [Report on Archaeological Works on the Territory of the Ural Region in 1980]. Arhiv IA im. A. Margulana NAN RK, op. 2, d. 1838.

Narty, 1989. Osetinskiy geroicheskiy epos. V 3 kn. Kn. 2 [Narty. The Ossetian Heroic Epic in Three Books. Book 2]. Moscow, Nauka Publ. 492 p.

Ol'hovskiy V.S., 1991. Pogrebal'no-pominal'naya obryadnost' naseleniya Stepnoy Skifii (VII-III vv. do n.e.) [Funeral and Memorial Rites of the Population of Steppe Scythia (VII-III centuries BC)]. Moscow, Nauka Publ. 253 p. 
Ochir-Goryaeva M.A., 1987. Pogrebal'nyy obryad naseleniya Nizhnego Povolzh'ya i Yuzhnogo Priural'ya VIIV vv. do n.e. [Burial Rite of the People of the Lower Volga River and the Southern cis-Urals in the VIIV Centuries BC]. Arkheologicheskie issledovaniya Kalmykii [Archaeological Researches in Kalmykia]. Elista, KRI HPhE, pp. 35-53.

Ochir-Goryaeva M.A., 1996. Nakonechniki strel kochevnikov Nizhnego Povolzh'ya [Arrow-Heads by Nomads of the Lower Volga River Region]. Rossiyskaya arkheologiya [Russian Archaeology], no. 1, pp. 41-54.

Pererva E.V., 2020. Paleopatologicheskie osobennosti kochevnikov savromatskogo vremeni s territorii Nizhnego Povolzhia [Paleopathological Features of the Nomads of the Sauromatian Time from the Territory of the Lower Volga Region]. Genesis: istoricheskie issledovaniia [Genesis: Historical Research], no. 12, pp. 171183. DOI: https://doi.org/10.25136/2409-868X.2020.12.34412.

Pikalov D.V., 2014. Bliznechnyy kul't i obychay otrubaniya ruki u sarmat [The Twin Cult and the Custom of Cutting off Hands and Sarmatians]. Trudy IV (XX) Vserossiyskogo arheologicheskogo s'ezda v Kazani [Proceedings of the IV (XX) All-Russian Archaeological Congress in Kazan], vol. II. Kazan, Otechestvo Publ., pp. 150-153.

Propp V.Ya., 1986. Istoricheskie korni volshebnoy skazki [The Historical Roots of a Fairy Tale]. Leningrad, LSU. 364 p.

Prohorova T.A., Guguev V.K., 1992. Bogatoe sarmatskoe pogrebenie v kurgane 10 Kobyakovskogo mogil'nika [A Rich Sarmatian Burial in Kurgan 10 of the Kobyakovo Cemetery]. Sovetskaya arheologiya [Soviet Archeology], no. 1, pp. 142-161.

Roginskiy Ya.Ya., Levin M.G., 1978. Antropologiya: uchebnik dlya studentov un-tov [Anthropology: A Textbook for Students]. Moscow, Vysshaya Shkola Publ. 528 p.

Simonenko A. V., 1993. Sarmaty Tavrii [The Sarmatians of Tauria]. Kiev, Naukova dumka Publ. 144 p.

Skripkin A.S., 2007. Klinkovoe oruzhie rannih kochevnikov Nizhnego Povolzh'ya VII-IV vv. do n. e. (problemy hronologii) [Bladed Weapons of the Early Nomads of the Lower Volga Region of the VII-IV Centuries BC (Problems of Chronology)]. Vooruzhenie sarmatov: regional'naya tipologiya i hronologiya: dokl. $k$ VI Mezhdunar. konf. «Problemy sarmatskoy arheologii i istorii» [Armament of the Sarmatians: Regional Typology and Chronology. Reports for the VI International Conference "Problems of Sarmatian Archeology and History"]. Chelyabinsk, SUSU, pp. 38-50.

Smirnov K.F., 1961. Vooruzhenie savromatov [The Armament of the Sauromats]. Materialy i issledovaniya po arkheologii SSSR, no. 104. Moscow, AS USSR. 101 p.

Smirnov K.F., 1964. Savromaty. Rannyaya istoriya i kul 'tura sarmatov [The Sauromats. Early History and Culture of the Sarmatians]. Moscow, AS USSR. 377 p.

Takazov F.M., 2015. Obychay otrubaniya ruki: skifo-nartovskie paralleli [The Custom of Cutting Off the Hand: Scythian-Nart Parallels]. Nartovedenie v XXI veke: Sovremennye paradigmy interpretatsii [Nart Studies in the XXI Century: Modern Paradigms of Interpretation], no. 3, pp. 142-151.

Tolstoy N.I., Tolstaya S.M., 1974. K semantike pravoy i levoy storony v svyazi s drugimi simvolicheskimi elementami [On the Semantics of the Right and Left Sides in Connection with Other Symbolic Elements]. Materialy Vsesoyuznogo simpoziuma po vtorichnym modeliruyushchim sistemam [Materials of the All-Union Symposium on Secondary Modeling Systems], no. 1 (5). Tartu, TSU, pp. 42-45.

Tsagaraev V.A., 2000. Zolotaya yablonya nartov: istoriya, mifologiya, iskusstvo, semantika [The Golden Apple Tree of Narts: History, Mythology, Art, Semantics]. Vladikavkaz, Respublikanskoe izdatel'sko-knizhnoe predpriyatie im. V.A. Gassieva Publ. 299 p.

Chibirov L.A., 2017. Pravaya ruka - desnitsa: skifo-osetinskie paralleli [The Right Arm - the Sword Arm: ScythianOssetian Parallels]. Vestnik Vladikavkazskogo nauchnogo centra [Vestnik of Vladikavkaz Scientific Centre], vol. 17, no. 2, pp. 24-27.

Chibirov L.A., Vol'naya (Kertseva) G.N., 2020. Voinskie obychai i obryady v osetinskom nartovskom epose: istoki i paralleli [Military Customs and Rituals in the Ossetian Nart Epic: Origins and Parallels]. Izvestiya SOIGSI [Izvestiya North Ossetian Institute for Humanitarian and Social Research], iss. 37 (76), pp. 5-16. 


\section{Information About the Authors}

Mariya A. Balabanova, Doctor of Sciences (History), Professor, Department of Russian and World History, Archeology, Volgograd State University, Prosp. Universitetsky, 100, 400062 Volgograd, Russian Federation, mary.balabanova@volsu.ru, https://orcid.org/0000-0002-1565-474X

Valeriy M. Klepikov, Candidate of Sciences (History), Associate Professor, Department of Russian and World History, Archeology, Volgograd State University, Prosp. Universitetsky, 100, 400062 Volgograd, Russian Federation, valery.klepikov@volsu.ru, valery.klepikov@mail.ru, https://orcid.org/0000-0003-2891-7366

Evgeniy V. Pererva, Candidate of Sciences (History), Associate Professor, Department of Russian and World History, Archeology, Volgograd State University, Prosp. Universitetsky, 100, 400062 Volgograd, Russian Federation, evgeniy.pererva@volsu.ru, perervafox@mail.ru, https://orcid.org/0000-0001-8285-4461

\section{Информация об авторах}

Мария Афанасьевна Балабанова, доктор исторических наук, профессор кафедры отечественной и зарубежной истории, археологии, Волгоградский государственный университет, просп. Университетский, 100, 400062 г. Волгоград, Российская Федерация, mary.balabanova@volsu.ru, https://orcid.org/0000-0002-1565-474X

Валерий Михайлович Клепиков, кандидат исторических наук, доцент кафедры отечественной и всеобщей истории, археологии, Волгоградский государственный университет, просп. Университетский, 100, 400062 г. Волгоград, Российская Федерация, valery.klepikov@volsu.ru, valery.klepikov@mail.ru, https://orcid.org/0000-0003-2891-7366

Евгений Владимирович Перерва, кандидат исторических наук, доцент кафедры отечественной и всеобщей истории, археологии, Волгоградский государственный университет, просп. Университетский, 100, 400062 г. Волгоград, Российская Федерация, evgeniy.pererva@volsu.ru, perervafox@mail.ru, https://orcid.org/0000-0001-8285-4461 